\title{
African witchcraft in theological perspective $^{1}$
}

\author{
I W C van Wyk \\ Hervormde Teologiese Kollege \\ University of Pretoria
}

\begin{abstract}
This article is a theological contribution aimed at creating an understanding of the phenomenon of witchcraft in South Africa. Witchcraft still causes major social problems in this country. The article argues that the development of a culture of human rights and the improvement of the judicial process alone will not solve this problem. Witchcraft is a too deeply rooted religious phenomenon. The phenomenon is described in its religious complexity and diversity. Witchcraft is discussed within the framework of the African theodicy.
\end{abstract}

\section{INTRODUCTION}

Throughout the ages, witchcraft has been one of the big problems of humanity. It has affected almost all countries and peoples at some stage of their history and in certain countries it still is the case. Witchcraft is without doubt one of the universal human problems (and is recognised as such by us as South Africans and you as Swedes). ${ }^{2}$

Witchcraft has always been a major problem in Africa (Mönnich 1967:78-97; Sundkler 2000:94-95, 347, 358, 378). This statement is underlined by the fact that African Traditional Religion (ATR) and African healing practices have as one of their most important functions the struggle against witchcraft. This problem is one of the most fundamental problems of African existence. Older scientific studies on witchcraft (e g Mbiti 1985:195197 and Bosch 1987:42-43) include extensive reports on interviews with

\footnotetext{
${ }^{1}$ The article is based on lectures on this topic presented at the Universities of Karlskrona (203-2002) and Lund (21-3-2002) in Sweden, the lecturer's symposium of the Hervormde Teologiese Opleiding (24-7-2002) and the CTT for ministers of the HKSA in Hammanskraal (14-11-2002) and Dududu (9-7-2003). The lecture style was retained for the purposes of this article.

${ }^{2}$ Recent research has exposed the magnitude of the present day problem in the United States. One example: Leininger 1994.
} 


\section{African witchcraft in theological perspectives}

Africans enquiring about the reality and actual existence of witches and witchcraft. According to those reports questions on whether or not witchcraft is a reality, are typical white man's questions. Africans never ask such questions, because to them witches and witchcraft are part of their everyday reality. Older and recent popular-scientific studies report extensively on the living reality of witchcraft or "black magic" (e g Campbell 1998:115-117; Holland 2001). Many lecturers at the various theological faculties and seminaries in South Africa (e g Van Niekerk 1992:44-64), including myself, can recount many stories of what they have personally witnessed in this regard or can recount what they have been told about witchcraft.

We also know that not only witchcraft, but also witch-hunts and witchkillings (killing of witches) have been a serious problem in South Africa during the last decades. The following statistics highlight the enormity of the problem: In the Limpopo Province of South Africa 445 witchcraft-related cases were reported to the police between 1990 and 1995. During 1996 a total of 1,182 cases were reported; during 1998 a total number of 554 cases and between January and September 1999 a total number of 739 cases were reported. Between 1990 and 1994 over 300 people were killed, and between April 1994 and April 1995, 228 people were allegedly killed as a result of witchcraft accusations/suspicions (Minnaar 1991:54, Mashangoane 2001:489). In the year 2000, 1300 witchcraft-related crimes were reported to the police in this province (SANPAD 2003:3).

In the Bushbuckridge district in the Mpumalanga Province, 21 witches were violently attacked between 1971 and 1985. The comrades (politically motivated youth) attacked 10 witches between 1986 and 1989. Over Christmas time in 1990, 34 witches were attacked in a witch-hunt. In 1993, 8 people and in 1994, 9 people were accused of witchcraft (Niehaus 2001:202207).

The fact that many of these killings took place amidst an extremely unstable political situation, cannot be disputed and the political motives behind many of these murders cannot be disputed (Niehaus 2001). Together with people such as Minnaar (1991) and Mihálik \& Cassim (1993), I am, however, convinced that the witch-killings in South Africa are not only to be explained in terms of political conflict. This problem is not only a problem characteristic of the struggle years against apartheid in the former homelands of Lebowa, Gazankulu and Venda. It problem is an everyday reality in many communities all over the country. Recently (in 2002), Erik Bähre published an article on witchcraft in Cape Town in the post-apartheid South Africa in which he asserted that witchcraft is a huge problem among Xhosa migrants in Cape Town. 
My own research within the Hervormde Kerk in Suidelike Afrika (HKSA) indicates that witchcraft is one of the major problems that students and ministers have to face.

A. Results of research undertaken among 17 students of Hervormde Teologiese Opleiding (HTO) during 2002/3

\begin{tabular}{|l|c|}
\hline Previously bewitched at home or school & 10 \\
\hline Bewitched at the HTO & 0 \\
\hline Have witnessed a witch-killing & 6 \\
\hline Have taken part in witch-killings & 2 \\
\hline Witchcraft is (one of) the biggest problems known to them & 16 \\
\hline $\begin{array}{l}\text { Require theological training to be better equipped to handle the } \\
\text { issue of witchcraft }\end{array}$ & 17 \\
\hline
\end{tabular}

B. Results of research undertaken among 11 ministers that have participated in the CTT, 11-12 July 2002 in KwaZulu-Natal.

\begin{tabular}{|l|l|}
\hline Had been bewitched in the past & 2 \\
\hline Had recently been bewitched . & 1 \\
\hline Has witnessed a witch-killing. & 1 \\
\hline $\begin{array}{l}\text { Witchcraft is (one of) the biggest problems known to them in their } \\
\text { own society. }\end{array}$ & 7 \\
\hline $\begin{array}{l}\text { Poverty, AIDS, marital problems and ancestor veneration are } \\
\text { bigger problems. }\end{array}$ & 3 \\
\hline Witchcraft is a problem within the HKSA itself. & 4 \\
\hline $\begin{array}{l}\text { Require theological training to be better equipped to handle the } \\
\text { issue of witchcraft }\end{array}$ & 7 \\
\hline $\begin{array}{l}\text { Do not want the church to become involved in the issue of } \\
\text { witchcraft. }\end{array}$ & 1 \\
\hline
\end{tabular}

C. Results of research undertaken among 16 ministers that have participated in the CTT, 14-15 Nov 2002 in Hammanskraal.

\begin{tabular}{|l|l|}
\hline Had been bewitched in the past. & 1 \\
\hline Had recently been bewitched. & 0 \\
\hline Has witnessed a witch-killing. & 0 \\
\hline $\begin{array}{l}\text { Witchcraft is (one of) the biggest problems known to them in their } \\
\text { own society. }\end{array}$ & 7 \\
\hline $\begin{array}{l}\text { Poverty, AIDS, marital problems and ancestor veneration are } \\
\text { bigger problems. }\end{array}$ & 12 \\
\hline Witchcraft is a problem within the HKSA itself. & 5 \\
\hline $\begin{array}{l}\text { Require theological training to be better equipped to handle the } \\
\text { issue of witchcraft }\end{array}$ & 14 \\
\hline $\begin{array}{l}\text { Do not want the church to become involved in the issue of } \\
\text { witchcraft. }\end{array}$ & 2 \\
\hline
\end{tabular}




\section{African witchcraft in theological perspectives}

The pervasiveness of the problem of witchcraft in present-day South Africa also becomes clear when the many initiatives to combat the negative effects of witchcraft, namely witch-hunts and witch-killings, are considered. It is also evident that a multi-disciplinary approach is called for, which again underlines the need for a theological contribution. It has become clear that the normal legal process, based on the Witchcraft Suppression Act 3 of 1957, amended in 1970 by Act 50, will not halt the many killings of especially older women. In September 1998, the Commission on Gender Equality convened the first National Conference on Witchcraft Violence with the aim of making a contribution towards halting witch-killings in South Africa (cf Mashangoane 2001). What emanated from the conference, and especially from ensuing discussions was the fact that Western-orientated legal methods will not solve this problem. This "African problem" that forms part of African philosophy and religion will not be solved by "Western" courts and police services (Peltzer 2001b). Neither Western education, nor the Western human rights culture will solve this problem (as advocated by Holland 2001:198-207. In this regard, see in particular Hund 2003).

Most people (at least in South Africa) would agree that it is the church's task to counteract human behaviour that is not reconcilable with God's law or a culture of human rights. Most people would also agree that such efforts should be ecumenical efforts. However, it is easier said than done as the issue at stake is a highly sensitive one which could even be regarded as a sensitive racial issue. African scholars constantly complain about the ignorance, prejudice and falsification that still emanate from modern books, newspapers and conversations on this subject by Europeans. To them the many distorted ideas that prevail still prevail among missionaries and European popular writers are annoying (Mbiti 1985:194). I tend to believe such sensitivity to be rather unfounded as witchcraft is not an African problem, but a universal one. A study of African witchcraft assists in discovering not only the uniqueness of the African mind, but also the common humanity we share. By studying witchcraft one discovers how different yet identical we humans are. Therefore, people from different cultural backgrounds can and should work together to address this problem.

The main question outsiders will put to the church and its theologians is the following: What contribution can the church make? Given the fact that to a large extent witchcraft is a religious phenomenon, and not merely a sociological one that could be handled in terms of Western legal systems (Hund 2000, 2003), the church can assist in defining and explaining this form of human behaviour. In a world where African thinkers themselves do not pay much attention to the problem and Western scholars tend to force research 
into a sociological framework (Rosen 1972; Leininger 1994; Olupona 1991:17), theologians can and must make a useful contribution. When one understands specific human behaviour, is able to define it and can explain it from the perspective of a broader world-view, then one will enable people around you to act in a more responsible way. This does not mean that the church don't want to cooperate with the various judicial efforts in combating human rights violations. The church can and will give our full cooperation to the various efforts to resolve this issue (as suggested for instance by Mashangoane 2001 and the SANPAD Report of 2003), but its unique and useful contribution lies in our ability to understand social reality.

\section{WHAT IS WITCHCRAFT?}

\subsection{The European legacy}

Witchcraft is as old as humanity itself. Black magic, sorcery and witchcraft have always been part of tribal religion in all cultures, although the terms "witches - hekse - Hexen" and "witchcraft - Hexerei" had been used for the first time only in 1419/1428 (Stiglmayr 1959:308, Mohr 1993:123). Witchcraft was used to explain natural catastrophes and personal calamities, to attain freedom by accusing others, to give moral instructions by narrating stories about evil women and to make peace and restore harmony between enemies and quarrelling groups. A comprehensive study on witchcraft will at least have to include references to ancient Greek and Semitic cultures (Russell 1987: 416-417). This article will only concentrate on one aspect of European witchcraft, namely diabolical witchcraft, chosen because the European witchkillings can be of assistance in coming to an understanding of African witchkillings.

According to research, a few hundred thousand (mainly older) women were slain during the witch-hunts of the fourteenth, fifteenth and seventeenth centuries (see Rehberger 1992 for extensive information on these killings/slayings ). Many witch-killings occurred during the first big witch-hunt that took place between 1420 and 1520, especially in the central and western areas of Switzerland. During the second witch-hunt that took place in various European countries between 1560 and 1680, even more persons were killed. Notwithstanding the influence of the Renaissance and the Reformation, as well as education and scientific knowledge, some killings occurred as late as 1782/1786 in Kempten (Germany), as late as 1793 in Glarus (Switzerland) and as late as 1793 in Posen (Poland).

What is interesting is that these witch-killings did not commonly occur throughout Europe. It was more prevalent in certain countries and furthermore 


\section{African witchcraft in theological perspectives}

in certain regions within countries. Witch-killings did not occur in southern Italy or in Spain. In England, Ireland and Scandinavia it was a rare occurrence. The killing of witches predominantly occurred in northern Italy, France, Switzerland, Germany, Holland and Scotland. Most of the killings took place in the rural areas of Germany where superstition and idolatry were prominent phenomena. Religious convictions clearly played a major role in this tragedy. The following example is quoted to illustrate the point: During the second big witch-hunt certain parts of Europe experienced a tremendous drop in temperatures for which there was no apparent explanation and therefore it could only be ascribed to the devil and his troops (especially evil women).

The vast amount of research on this topic indicates that many other factors contributed to this tragedy. The witch-killings were clearly linked to the poor economic realities in the rural areas. The many wars, social unrest, instability and hopelessness all played a part in the witch-craze in Europe at the time. Even the resurgence of the sermon, insofar as it contributed to the rapid spreading of information about witchcraft, could be blamed for the killings (Russell 1987:419). Medieval lifestyles came to an end during the seventeenth century and many changes took place in the political and social spheres. These changes in political and social spheres became a breeding ground for uncertainty, disorientation and irrational human behaviour.

Notwithstanding the socio-cultural changes and the psychopathological misdemeanours that gave rise to these atrocities, theological convictions, incited by idolatry, superstition, uncertainty, anxiety and fear of the devil and other evil forces, were the real reasons behind this tragedy (Russell 1987:417-421).

The Early Church saw it as her duty to uproot witchcraft. Under the influence of Exodus 22:17 and Deuteronomy 18:10 (proclaiming the death penalty for such transgressions) and Roman law, the church started persecuting those guilty of witchcraft. Witchcraft was regarded as a rebellion against God and a rejection of Christianity. During the fifth and thirteenth centuries, witchcraft-accusations and the killing of witches widely occurred. Where these events did take place, the church, was however not officially involved in them. Although people evaded witch-killings during the early medieval times, the fear of and the need for a condemnation of witchcraft continued. In this regard the Canon Episcopi (AD 900) of the Frankish kingdom, condemning old women who went out at night on beasts with the pagan goddess Diana and other troops of the devil to harm innocent people, is a good example. During the thirteenth and fourteenth centuries the church began to persecute the "soldiers of the devil" with the sword. The question is: Why? The church became involved because of a specific theological thinking 
held with regard to evil. Thomas of Aquinas started a theological tradition in terms of which witchcraft was identified as one of the aspects of evil.

Witchcraft was equated to evil, for it was generally believed to amount to the formal repudiation of Christ, secret nocturnal meetings, nocturnal rides, the desecration of the Eucharist and the crucifix, orgies, sacrificial infanticide and cannibalism. At the first formal trials of heretics during the Middle Ages, held at Orléans in 1022, these were the accusations levelled at the accused (Russell 1987:417). During the fifteenth century theologians further developed this teaching on witches as part of the doctrine on evil (that concentrated on the devil). The unique feature of the research of this particular century was the fact that it did not concentrate on witchcraft as an individual sin, but as a collective threat. Witchcraft was seen not as a threat from individuals, but from groups of people that had formed a pact with the devil to cause disease, famine, storms and barrenness. The Dominican Johannes Nider (1437) was one of the prominent theologians in this regard. He developed the myth (based on the legend of Theophilus that dates back to the ninth century) that certain people formed a pact with the devil. His mythology paved the way for two members of the Inquisition, Heinrich Insitoris and Jakob Sprenger to write a handbook (1487) on witchcraft, The Witchhammer (Malleus maleficarum) which convinced the church to become actively involved (via the Inquisition) in witch-killings.

The atrocities committed by the Inquisition enjoyed the support of the popes. ${ }^{3}$ Since the thirteenth century they institutionalised the hounding, persecution and prosecution of heretics (which also included the belief in the worth of acts associated with witchcraft). They furthermore legitimised the teachings on witches. In this regard I wish to briefly refer to the following: The series of decrees between 1227 and 1235, which established the papal Inquisition; the authorisation/mandate? given to the Inquisition by Innocent IV in 1252 to torture heretics; the authority given to the Inquisition by Alexander IV in 1260 to handle all cases of sorcery; the publication in 1484 of the bull on witches (Summis desiderantes as a preface to the Malleus maleficarum) by Pope Innocence VIII, according to which he blessed the teaching on witches and the prosecution of witches. These issues all contributed to the eventual killing of witches.

\footnotetext{
${ }^{3}$ The recent (2003) book by Rainer Decker disputes many of the accusations leveled at the Inquisition and especially at the popes. He was one of the first persons to gain access to certain secret archives of the Faith Congregation, previously closed to the academic fraternity. According to Decker, fifty thousand people were killed in Europe as a consequence of witchcraft accusations, and of this figure only one thousand were sent to death by the popes. He asserts that the majority of people that died on the stakes lived within the boundaries of Protestant areas. This book is bound to elicit strong and emotional reaction.
} 


\section{African witchcraft in theological perspectives}

The clergy and the theologians were however not the only ones behind the witch-killings. Ordinary people and their religious thought also played a major role in the witch-hunts. Local populations, the common people, were actually the perpetrators of these killings? They were the ones who identified witches on behalf of the Inquisition. Their actions arose from their conviction with regard to the theological theories on evil and witches. However, the identification of witches was also based on pagan and distorted biblical views on women. Most of the time, women from poor rural areas who differed from the rest of society, were identified as witches. Especially those who dressed differently than the rest and who had a different look to what the norm had been, were prone to suspicions of witchcraft. Those women that showed an interest in learning were also prone to being identified as witches. Hatred, jealousy, covetousness and hostility among women were also major reasons for witch-hunts. Other factors that played a role in the identification process of witches included: Agricultural fears, the fear men had for single/unmarried women, the suspicions new scientific doctors had as far as the "secret knowledge" of traditional healers was concerned, scapegoat-thinking (someone had to be blamed for disease, famine etc), general hostility towards women and the evil imageries about women and their lust for sex upheld by the priests of the Inquisition who lived in celibacy (Mohr 1993).

Many people blame the churches, both Roman Catholic and Protestant churches for not playing an active role in stopping the witch-killings. They regard this failure as one of the church's big failures. Only a few individuals associated with the churches can be singled out for their efforts in stopping the killings. In this regard the efforts of the following individuals are generally recognised:

- $\quad$ The Jesuit Friedrich von Spee who wrote an article in 1631 in which the torture of people suspected of witchcraft, was criticised. Von Spee did not attack the notion of witchcraft, but only the unfair accusation of certain women.

- $\quad$ The philosopher of law, Christian Thomasius in Halle was one of the first persons to attack the superstition of witchcraft. He questioned on the existence of witches, and thereby also questioned the legitimacy of the legal procedures taken against the women. He furthermore objected to the torturing of "witches".

- $\quad$ Maria Theresa deserves special mentioning. She played a big role in the eventual abolishment of witch-killings. Many scholars are of the opinion that it was the enlightenment process that brought witch-killings to a halt during the eighteenth century. They believe that education and 
proper scientific research helped people to overcome their superstitions (for comprehensive information, see Brück 1959:308-310; Haag 1978:154-164; Vierzig 1984:33-35; 76-77; Schormann 1986:297-304; Russell 1987:414-423; Di Nola 1990:263-328; Mohr 1993:122-138; Küng 1994:697-702; Hauschild 1999:592-597; Haustein 2000:17191722; Decker 2003).

I am however of the opinion that the churches did play a decisive role in bringing an end to the accusations and killings. The development of theology and the spreading of the new understanding of man, sin, evil, God, grace and love brought an end to this madness. I am convinced that the religious beliefs of the common man were the single most important reason for witchcraft accusations and witch-killings. I am also convinced that new religious beliefs that developed among the common people during the eighteenth century have rid Europe of these problems.

We shall see that "diabolical witchcraft" is unknown to Africa. We shall also learn that many aspects of European witchcraft ought to be very familiar to Africans as there are many similarities. The research on European witchcraft can indeed help us in Africa to come to terms with our own problems.

Allow me one remark on the research in Europe. The research on Western witchcraft departs from the presumption that witches and witchcraft were (and are) not realities and therefore it (the research) concentrates on the wrongs committed by people who killed the so-called witches. It furthermore concentrates on the unfortunate circumstances and false teachings and beliefs that led to this tragedy. One aspect, however, does not receive the attention it deserves. It has to do with the question that tries to establish to what extent evil-minded people had contributed to the tragedy. For example, in many instances witchcraft accusations are related to issues such as child abuse and cannibalism. Can we honestly say that all cases should be linked to something such as innocent fate? How many cases could be linked to historically proven atrocities, especially against children? Should we always only concentrate on the innocence of the victims, and never on their possible guilt? (Please don't get me wrong on this score! I am not trying to justify any witch-hunt!) Should we always only see one type of evil in a serious light? Should we always neglect the sinful nature of humankind? I think we can learn something from African witchcraft. Africans taught me to open my eyes to the terrible things people do to others (especially children). 


\subsection{African perspectives}

In defining African witchcraft, one could start by stating that in general African witches and sorcerers are people with the mystical ability to manipulate the forces of life to do harm to human beings or their property. Or one could say that sorcery, witchcraft and black magic are the anti-social employment of mystical powers to harm others and their possessions. Witchcraft clearly is a term used to describe the evil (such as persistent illness or bad luck) that some people inflict upon others.

However, there are many different meanings to evil as witchcraft, has (Bongmba 2000:17). The evil of witchcraft has to be subdivided into many different categories. The word "witchcraft" (ubuthakathi -Nguni or baloyi Sotho, Pedi, Venda, Tsonga) is a generic term that could include a range of practical realities. Only by looking at the variety, the width and the depth of "witchcraft" will become transparent.

\subsubsection{Witchcraft, mystical powers and magic}

Belief in mystical powers prevails in every African village and township. Many stories are told to prove the existence of all kinds of powers and forces in the universe. Most Africans also believe that people have the ability to manipulate these powers and forces to their own benefit and to the detriment of others. They are convinced that certain people possess mystical powers that enable them to poison people from afar and to send snakes to their enemies (Fourie 1921:80-102). Over the years, many students have been utterly astonished when I dared to ask critical questions about these occult aggressions. Recently, a student informed me that the Hammanskraal community is convinced that the taxi accidents on the N1 south are caused by a flying witch that appears in the sight ahead of drivers, thereby obscuring their vision. It is this belief in mystical powers and the manipulation of these powers that open up the possibility and danger of magic, sorcery and witchcraft. Because people believe that all kinds of mystical powers exist and that people can control these powers, magic and witchcraft are everyday realities in every African society.

The term "witchcraft" is used to describe the magic activities of a variety of people that in various ways and through various methods, harm others in one way or another.

The first group of people associated with "witchcraft" is the so-called "witches". Witches are mainly older women (Stadler 1996:88). It is however a known fact that very young girls could also engage in witchcraft (Müller \& RitzMüller 1999:160-165). They have the power to free their spirits from their bodies at night, and then go out as spirits (or as animals or semi animals - or 
with these animals) to harm people in different ways - but importantly without knowing what they are doing. What is unique about these nocturnal witches is that they do not use "medicines" in their evil work. They either operate at a more spiritual, more direct level; or they operate with the help of animal familiars such as baboons ${ }^{4}$, owls, the lightning bird (impundulu) and cats. Their intentions are always evil. They are interested in death, disease and material loss. Their association with necrophagy (cannibalism in order to strengthen their spiritual power) makes them feared and despised people. All of their desires are at odds with African social values, such as helpfulness and solidarity. It is for this reason that they are hunted and killed. The evil of nocturnal witches is known to be collective efforts. Witches belong to secret clubs or societies. They plan their evil activities at secret meetings.

"Witchcraft" in most cases in this category therefore refers to the evil of groups of people. It is seldom the work of solitary individuals. There is no clear indication as to why people become witches. Remarkably, Africa gives the same explanations with regard to this mystery as the scientific fraternity would offer with regard to modern evil activities. Some believe that people are born witches; others believe the phenomenon to be hereditary and a few believe witchcraft is acquired through learning. Notwithstanding the fact that some people are convinced that witchcraft could be learnt, consensus would almost have it that there is no understandable motive for the misdemeanours of witches. As far as I am concerned this concept of "witchcraft" is a metaphor for the enigma of human evilness (Parrinder 1981:122-127; Marwick 1987:424; Nyirongo 1997:183-194; Turaki 1999:196-197; Müller \& Ritz-Müller 1999:138; Mashangoane 2001).

The second group of people associated with "witchcraft" is that of the so-called "sorcerers". Many scholars find it useful to distinguish between "witchcraft" and "sorcery". According to them, and I agree with this view, there is sufficient reason to keep these phenomena apart. This will be done in the knowledge that no clear distinction can be made between witchcraft, sorcery and magic (Hammond-Tooke 1989:73-74; Müller \& Ritz-Müller 1999:138; Ferdinando 1999:89-95; Peltzer 2001a:104).

Witches (boloi bja bosiu), as we have already indicated, are for the most part women that perform their evil deeds by night - and importantly without knowing what they are doing. Sorcerers (boloi bja mosegare) are mostly men who perform their evil deeds during daytime. They do not possess the ability to leave their bodies. Theirs is evil by intent. They do not harm and kill at random. They kill and harm for a specific purpose and with full

\footnotetext{
${ }^{4}$ The ministers and students of the HKSA regard baboons (tšwene - Sotho) as the main partners of the witches.
} 
knowledge of their evil acts. A sorcerer can therefore stop being a sorcerer, but a witch cannot stop being a witch (Mönnich 1967:71-78; Sundermeier 1990:228; Hammond-Tooke 1993:169; Magesa 1998:181; Magubane 1998:98).

Witches and sorcerers, as many other people in African society, have the ability to perform natural magic or thaumaturgy. They, however, use this ability for evil purposes. These people turn thaumaturgy into "black magic". They harm and kill over a distance by casting spells, using incantations and magic objects such as totems, "medicines", charms, amulets and talismans (Turaki 1999:193-194). The most notorious method evildoers use in harming others, however, is by using animals. I have already indicated that witches use animals or semi-animals in their evil work. The same applies to sorcerers. In South Africa, the thikoloshe or tokolotši (tokkolossie - Afrikaans) and the zombies (umkhovu or dug-up corpses) are known as the main myrmidons of witches and sorcerers. This short, human-like baboon is one of the most fearful creatures of the region. He controls many aspects of humans' lives, such as a person's sleeping habits. It is out of fear for this creature that people place their beds on bricks so that it would not be able to get unto their beds at night (Marwick 1987:425; Hambrock 1991:120-121; Hammond-Tooke 1993:170-171; Nyirongo 1997:185-187; Müller \& Ritz-Müller 1999:138-169; Bähre 2002:320-323). Most of the time evildoers use less spectacular items to assist them in their acts of evil. For example, nails, hair and feathers, in fact almost anything, could be used to harm others. Scholars have identified two different types of evil magic among witches and sorcerers where the use of these objects comes into play:

- $\quad$ Contagious magic: A magician (witch or sorcerer) can harm people simply by touching them. They can also harm people simply by doing something bad to parts of their body or to other personal belongings. People therefore are afraid to leave pieces of their hair, nails, clothes or other personal items about as evildoers could use these objects to harm them. For instance, if someone burns your hair, you will be set on fire. This type of magic is based on the belief that things that belonged together, will continue to have an influence on one another.

- Homoeopathic magic: Evildoers could for instance make a doll that resembles the enemy. By burning the doll, the person it resembles could die in a fire. This type of magic is based on the belief that what happens to an object that resembles another, will affect the latter (Mbiti 1975:166; 1985:199; Nyirongo 1997:185-186; Müller \& Ritz-Müller 1999:142; Turaki 1999:193-194). 


\subsubsection{Who are the witches?}

I have previously stated that I consider "witchcraft" as a metaphor for the mysteriousness of human evil. I would like to expound on this thesis by revealing various identikits of "witches".

\subsubsection{Witches are obscurant}

As was earlier mentioned, witches are mainly older women who harm people for no good reason, without being aware of what they are doing. Although societies may suspect certain individuals of being witches, they have no proof thereof. The public is in no position to know the real witches, because evil is a mystery. The evilness of evil is that it cannot be identified. ${ }^{5}$ Evil is - and therefore witches too are obscurant. A Northern Sotho proverb states: Moloi ga a na lenaka (a witch has no horn). This means: A witch's identity is never obvious. The same people say: Molôi ga a bônwe ka mahlo (a witch cannot be seen with the eye). People should therefore be cautious in accusing others of witchcraft (Hanekom 1972:124; Niehaus 1997:253).

In his study on the Dogon in Mali, Walter van Beek shows that this understanding of evil is fairly common in Africa. The Dogon people does not see evil as part of normal village life, but rather as something of the night and of the bush. Evil therefore is something from outside humanity. According to a Dogon saying witches don't have a shadow which signifies that witches cannot be known. But, at the same time they acknowledge the fact that "witches" are people or personalities. "Witches" therefore are normal persons from within the community, but the community does not know who they are. Society therefore can do little about evil. There are no real solutions to the problem. When evil is among you, but you do not know what it is, then nothing can be done about this problem (Van Beek 1994:207-212).

\subsubsection{Witches are different and unusual}

Notwithstanding the fact that witches and their "crafts" are obscurant, society still experiences the need to identify these witches. Societies often tend to accuse people who are different and unconventional of being witches. People, therefore, use the word "witchcraft" to align to evilness people and their activities that are different, that is to say people and behaviour that differ from the normal and conventional. Very often those people in society that appear to be "very strange" are identified as witches and sorcerers. They are persons known to all, but with whom one does not want to be associated. They are persons with all kinds of abnormalities, such as sterility or bodily deformities

\footnotetext{
${ }^{5}$ This is general religious knowledge. Various Christian theologians have been exponents of this notion.
} 


\section{African witchcraft in theological perspectives}

such as red eyes or ugly feet or are diseased. They are people whom many would classify as "insane". They are known for their queer or malicious behaviour - such as having animals as partners - in more than one sense. Women known for their solitary behaviour are also easily identified as witches. People simply assume that these types occupy themselves with evil in some form or the other. (Thorpe 1993:105; Müller \& Ritz-Müller 1999:140; Ferdinando 1999:95-96).

The term could also be used to refer to people associated with excessiveness. A witch could simply be someone who has more "power" than others, or a person who has more abilities, possessions and success than the average man and woman. In Africa "witchcraft" designates the activities of people who are different, people who are known for the extraordinary - people who have more, look differently and perform better than the average person. Very old people, exceptionally clever students, extremely rich people, very beautiful women and very ugly men could all be identified with witchcraft and sorcery (Sundermeier 1990:230; Kriel 1996:97-99; Magesa 1998:179).

\subsubsection{3 "Witches" are ordinary people with anti-social behaviour}

The word "witchcraft" could also be used to describe the evil actions of very ordinary people. "Witchcraft" could be used to describe the bad things good people do. It is often used to describe the mystery of good people suddenly and for no reason whatsoever, doing things that are unacceptable. For this reason "witches" and "sorcerers" are very often not the strange people in society. The ordinary man and woman in a village could suddenly become a witch and a sorcerer.

What then are the tings normal people do that would earn them the title of witch? What is so evil about the things they do? What do these people do that turn them into such hated beings? Some people are called "witches" because they cause destruction. The destruction they cause is the inversion of the normal, well-balanced life (the traditional accepted life). In Africa the anti-social behaviour of normal people is regarded as "witchcraft" (Thorpe 1993:116; Müller \& Ritz-Müller 1999:139). Let me cite a few examples:

- People who contravene accepted norms and destroy the basic values of society, such as rejecting respect for seniors;

- People who destroy the harmony in society by destructing the normal and the good in society, such as having intercourse with animals (bestiality) or with the same sex (homosexuality);

- People who harm others close to them, such as family members - especially children; 
- People who are guilty of incest, or who have incestuous dreams;

- People whose actions are characterised by secrecy and loathsome behaviour;

- $\quad$ People who eat human flesh - especially that of children;

- $\quad$ People who upset the balance of nature.

(Olupona 1991:180; Hammond-Tooke 1993:173; Magesa

1998:185-186).

\subsubsection{Why witchcraft?}

I have up to now argued that a wide variety of persons could be identified as witches and that a range of deeds and actions could be associated with witchcraft. It is not only the supernatural and extraordinary deeds of very peculiar and fearsome people that are associated with witchcraft, but also the behaviour of "normal" people that is socially unacceptable. The question that needs to be answered next is: Why do people resort to witchcraft? Why do people want to harm others?

Africans know that "witchcraft" is not restricted to some strange old woman somewhere in the night. It is ubiquitous. It can be witnessed in all areas of life and in all aspects of social life. No situation can claim to be free of "witchcraft" All people can, for some reason or another, engage in "witchcraft". "Witchcraft" is therefore not a craft or an art. It bears witness to the mystery that people harm others and destroy human relationships and the harmony of society for reasons not always known to us. Africans explain evil as an anthropological reality. The source of evil never lies with God or the "devil", but can always be traced to humans themselves. The studies of Van Beek (1994:197-207) among the Kapsiki of Northern Cameroon reaffirm this assertion. His research reaffirms the point that Africans explain evil only in terms of an anthropological frame of reference.

However, the question still remains: Why do people harm other people? Throughout Africa everything points to jealousy as the answer to this question. It is jealousy that drives people to harm others. Jealousy causes people to hate others and to destroy lives. It forms the basis of fear and the obstacle for co-operation. Jealousy is the reason behind the destruction of the community and the exploitation of society for personal ends (Ray 1976:150152; Turaki 1999:193-194; Müller \& Ritz-Müller 1999:143; SANPAD 2003:13). By indicating "jealousy" as the most profound cause of "witchcraft", Africans concentrate on one very important aspect of evil. By attributing it to jealousy, they stress the fact that most of the time witchcraft (as well as other acts of evil) is not the result of legitimate anger, but arises from the urge to harm 


\section{African witchcraft in theological perspectives}

people who have more than you, who are more successful than you are and who have better looks than you have. "Witchcraft" therefore is a desire, a craving, and a passion to harm others who have more than you and who achieve more than you do. "Witchcraft" therefore is a metaphor for one aspect of human "sinfulness" that we as Christians would term the "Cain-factor".

The African concept of "witchcraft" does not only overlap with certain aspects of the Christian notion of "sin", but also with certain aspects of the notion of "original sin". Africans, as well as Christians, know that the potential to do evil vests with all. Africans know that anyone could be a witch or could become one. Therefore, they know that every person is a potential witch. Every person has this potential power. It just remains latent in most people. According to African thinking evil is situated in the liver - that is in everyone's liver (we just refer to the heart as the center of evil). Emotions of envy, hatred, lust and jealousy fill us all. But why do all people succumb to "sin"? Africans as Christians - say it is because of man's situatedness in society. Africans know very well that "sin" (in the form of witchcraft) is embedded in human society. In certain instances witchcraft is committed wittingly, and in other instances it is committed unwittingly (because the doer is overcome by a preexisting evil in society). Therefore, they know that sin and evil must be traced back to more than mere individual choice. Society turns people into witches. Africans teach that witchcraft can be transmitted by mother's milk and can be learnt at home. We as Christians can identify with this argument. We also teach that $\sin$ is transmitted from one generation to the next (be that through sexuality or not). We also teach that we are born into sin; the sin that already exists in society (cf Hammond-Tooke 1993:172; Magesa 1998:181-184; Ferdinando 1999:97).

Notwithstanding the fact that all people know that "witchcraft" is a mystery and that anyone could succumb to this kind of evil, people still have the urge to accuse certain people of witchcraft. Accusations of witchcraft mostly occur in closely-knit communities with limited resources. In closed communities that experience financial problems, relatives and neighbours are most often accused of witchcraft. Accusations of witchcraft abound in situations of domestic tension and strained relationships due to bad economic circumstances. In circumstances of hopelessness people readily believe their life power to have been taken away from them (and that is why they are poor or ill). To restore this "power", they have to either harm or kill their adversaries.

Jealousy and envy drive people to accuse others of witchcraft. Africans doubt whether it is possible for ordinary folk to have success on their own. It is believed that ordinary people that are successful must have achieved their 
success by making use of other people's life-force, or of some kind of "muti". Those that are highly successful could even be accused of a muti-murder (Minnaar 1991:53-54). In the past, women who were academic achievers were accused of witchcraft, because women were believed to be inferior to men in all respects. Today, these women are accused of witchcraft, because of the feelings of inferiority of men who are not prepared to work in order to achieve success within the parameters of a "new society". The accusation could also apply inversely. In my own research I have increasingly found that people are accused of witchcraft because they are believed to hamper educational, financial and social progress (cf Reyneke 1972:154; Bosch 1974:74; Mbiti 1975:167; 1985:199; Parrinder 1981:131-134; Nyirongo 1997:187-188).

According to Niehaus (1997:271-272) not all witchcraft accusations can be traced back to social tensions. Sociological explanations are not the only explanation for witchcraft and counter-witchcraft. Not even the visible actions of jealousy, envy, malice and resentment can cover all the cases of witchcraft and witchcraft accusations. According to him divination, in the form of dreams, plays a major role in witchcraft activities. Such extra-social revelatory knowledge has a huge impact on the lives of Africans. We must accept that non-rational elements (such as dreams and hallucinations) are important tools in witchcraft activities, as well as in witchcraft accusations.

\subsubsection{The vicious cycle of fear caused by witchcraft}

Africans (as all other people) believe that there are many evil-minded people that want to cause harm to them. They believe in the existence of people who can leave their bodies at night in a supernatural way to harm them - simply for the pleasure of hurting them. They also believe there are people that could plan to hurt and harm them. They believe for instance that such people have the power to harm them over distance by manipulating animals and by poisoning their food. They believe that jealous people, who could deliberately inflict harm upon others in an attempt to improve their own life situation, can be found everywhere.

It is normal human behaviour to protect oneself against the attacks of evil-minded people. Africans try to protect themselves against "witchcraft" by using herbal medicines as well as magic medicines that are stronger than the evil that threatens them (Mbiti 1985:197-198).

Various groups of people provide "medicine" that could be used to counter "witchcraft". The first group is the "herbalists" ("pharmacists" or "primary health workers" - Campbell 1998:1). They provide people with "medicine" similar to Western medicines. In the Basotho and Mamabolo 


\section{African witchcraft in theological perspectives}

traditions the Ngaka can diagnose disease and can prescribe remedies. In the Nguni tradition, this task vests with the inyanga yokwelapha and the isangoma. These herbalists can also provide "medicine" to protect people against sorcery and disaster. Sometimes the medicine is provided as the result of professional knowledge, and sometimes it is issued with the help of ancestors (Fourie 1921:82-84; Hanekom 1972:112; Magubane 1998: 61-62).

The second group could provide people with "medicine" unfamiliar to the scientific fraternity. It could be described as providing people with "good magic". These "practitioners" (bongaka - Tswana, isangoma- Basotho) can also be called "medicine men" and "herbalists". In most instances they are called "diviners", "mediums", "rainmakers" and "priests". They are the friends of society. They have the knowledge to apply mystical powers to the benefit of society. They are therefore often referred to as "good magicians" or "good witchdoctors". These good magicians who have the ability to perform "white magic" or theurgy, provide people with concentrated mystical power in the form of charms, amulets, powders and feathers. These objects, filled with good powers, are used for counteracting misfortunes, undoing curses and in destroying witchcraft (Reyneke 1972:146-147; Turaki 1999:193-195). These "medicines" are often called "muti". "Muti" as part of the armament of "white magic" could protect, heal or bring good fortune, because it is more powerful than the elements used by the witches.

"Muti" could, however, also be used in a way, far removed from theurgy. As assistance to victims, witchdoctors could also provide them with "muti" that could be used in revenge (letswa) against evil people. The abhorrent aspect of such "muti" is that it could also comprise parts of the human body, because body parts (especially sexual organs - Fourie 1921:85) make the strongest "medicine". Such "muti" does not only cure and protect, but can also harm and could even kill. Africans believe that only magic can be used in defence against the magic of another. They would therefore pay huge sums of money to acquire magic potions or "muti" that would be strong enough to counteract the evil of others (Crafford 1996:16-17; Magubane 1998:113; Müller \& Ritz-Müller 1999:143-146).

Where magic is not only employed for defensive and protective purposes, but also for offensive purposes, it again becomes an issue of "black medicine", "black magic" and sorcery (Turaki 1999:116-117). In Africa the dividing lines between good and bad, victim and aggressor, healer and murderer are clearly very narrow.

People confronted by "witchcraft" also seek help from a third group of traditional healers, known as "diviners" in the English language and as "dolosgooiers" in the Afrikaans language. These diviners are also called 
ngaka - Tswana or inyanga yokubhula - Nguni or senohe - Sotho (Magubane 1998:113). This group is consulted for their knowledge of the source of this evil. They specialise in the divination of the buloyi. They have the ability to see whether a disease or a misfortune is to be traced back to the evil deeds of a "witch". They have the gift of literally smelling out the evildoer (Magubane 1998:61-62. 98). They help their clients by identifying the "witch" through the help of the ancestral spirits, by throwing stones or "dolosse" (ditaola), shells, seeds and artefacts or by interpreting dreams (Reyneke 1972:146-147; Hanekom 1972:114). Many female diviners get their (reliable) information via dangerous snakes. It is believed that many ancestors live inside these snakes. Due to a special relationship between the diviners and the ancestors, the snakes don't bite them. When these methods fail to provide the information needed, a last method can be resorted to, namely the swallowing of poison (in the expectation that the guilty would die and the innocent would live). To the Western mind such "judicial process" amounts to nothing less than injustice. Africans reason differently - to them witches are unknown. Therefore, a trial with witnesses would be inappropriate. A witch has to be smelled out; and for this experts in the trade should be used (Krige 1981:225226; Myburgh 1991:122-123).

Once the diviners have identified the foe with the help of the ancestors ${ }^{6}$, they can prescribe a remedy or a plan of action which could even include a witch-killing. The latter could take the form of sticks being stuck up the anus, stoning, spear-killing, banishment and being thrown to crocodiles (Reyneke 1972:152-180; Krige 1981:226-227; Parrinder 1981:106-114; Sundermeier 1990:232-239; Thorpe 1993:113-120; Magesa 1998:189). These people who act as the defenders of society against witchcraft, tragically, are the same people who lead witch-hunts (sometimes through secret societies) that could easily end up in a witch-killing. By fighting "bad magic", they become part of a new cycle of destruction and death. These friends of society are the very people responsible for maintaining a vicious cycle of revenge and counter-revenge (Parrinder 1981:106-130; Olupona 1991:145).

\section{A BROADER PERSPECTIVE ON WITCHCRAFT}

\subsection{The African theodicy as the solution to the problem of evil}

All peoples on earth are confronted with evil. Different peoples understand evil differently, they define it differently, they explain it differently and they handle it

\footnotetext{
${ }^{6}$ This is however not the only way followed when accusations of witchcraft are made. According to the PANSAD Report (2003:11-21) "public discourse" is another important route taken with regard to these accusations.
} 
differently. African societies, and African Traditional Religion, have developed a unique framework in terms of which they understand, define and deal with evil. To a certain extent, this framework is typically African (or typical of tribal existence) - but, as we shall see, it is indeed typical of humanity as a whole. Most societies think and argue in exactly the same way.

Witchcraft or black magic functions as an explanation for evil ${ }^{7}$. It provides an answer to the mystery of why bad things happen (to good people) in this world. Because natural explanations of the bad often fail - or do not provide satisfactory answers, the need to explain the unexplainable still remains. Witchcraft offers Africans a way of explaining the unexplainable. Magic and witchcraft help people to explain their human experiences of pain, suffering and sorrow within the wider perspective of human relationships; and in this way assist in making life bearable (Mbiti 1975:174; Stadler 1996:110; Magesa 1998:182).

In the Western Christian tradition, we tend to deal with the problem of evil in terms of a "theodicy" (the study of Hermanni 2002 offers one of the most recent comprehensive studies on this subject). The "theodicy question" as we know it in Christian theology, however, does not concern ATR. The question: "Why do things happen?" is not frequently asked. The question: "How can one reconcile the idea of a loving and almighty God with the reality of evil?" is unknown to Africans (Gyekye 1998:468-470). To them the question of importance is: "Who caused something to happen?" If harm has come to a person, he believes that someone has used evil powers against him. More often than not the culprit would be a family member, a relative or a neighbour (Mbiti 1975:164-5; Minnaar 1991:53-55).

In Africa there is clearly no room for a cosmic dualism (such as a devil causing evil problems - Bosch 1974:74-89). To Africans evil is an anthropological reality. Evil can only be attributed to human beings. The origin of evil and the reason for its continued existence is man and man alone. The question about evil as such (an sich) is senseless to Africans. Africa is only interested in the practical fight against evil. In order to fight evil, the cause must be known. The cause of evil in Africa is always the other one (and neither God nor the ancestors - Hammond-Tooke 1989:47-48; 1993:178). Witches are the others being responsible for evil. When witches are identified the inexplicable could be explained. According to Africans (and they are not

\footnotetext{
${ }^{7}$ Accept my interpretation as only one of many possibilities. Witchcraft is an extremely complex phenomenon, and could therefore be explained in terms of various models of interpretation. Recently, Bähre (2002) for instance offered a legitimate explanation of witchcraft in terms of fantasies about sex and money and Niehaus (2002) interpreted it in terms of the perversion of power. For an overview of the intellectual, psychological, sociological and religious explanations, see Ferdinando (1999:117-128).
} 
alone in this belief), suffering becomes bearable when one knows who causes it (Sundermeier 1990:133, 231).

In Africa evilness is clearly restricted to evil persons. Evil persons are those known for their use of bad magic, sorcery and witchcraft to harm others. Africans therefore see magicians, witches and sorcerers as the evil of society. They are the ones behind all the bad things that happen. Even natural catastrophes, such as droughts and earthquakes, are not viewed as enemies, because someone - some evil-minded person - would be behind such occurrences. Thus, someone is ultimately responsible for most of the catastrophes in life. Someone has manipulated the forces of nature to harm others.

Africans would not deny that ancestors, and even God, could be responsible for some evil occurrences. However, they are not seen as evilminded beings as such. A quest for a theodicy, in the Christian theological tradition, has no urgency in Africa. What would interest Africans is namely the question "who caused the ancestors or God to act in anger?" Who did not obey traditional norms and taboos, or who did not bring their sacrifices?

Notwithstanding the fact that ATR is not interested in the theodicy problem as it is formulated in the Western Christian tradition, it however does not mean that ATR does not have its own kind of theodicy (or to be more precise: an "aetiology of misfortune") in terms of which the problem of evil is dealt with. Witchcraft has a "theodetical function". It provides an answer to the "why question" by saying: "The reason for there being illness and misfortune, is because someone has caused it". The belief in witchcraft therefore provides an explanation for illness and misfortune. The belief in mystical powers and the ability of man to manipulate those powers help people in finding explanations when things go wrong. Knowing how a disease is caused does not satisfy them, as they want to know who caused the disease to attack them. This answer harmonises with the view of the universe that acknowledges that there are many invisible forces at work, some of which are available to human beings. The answer also harmonises with the view that that which is bad in life, such as disease, is caused by poor inter-personal relationships. This type of theodicy feeds on the African philosophical notion of "cause" as being one of the cornerstones of the African view of reality (cf Sogolo 1998:177-185).

\subsection{The negative consequence of this type of theodicy}

The logic behind the belief in witchcraft is the assumption that there is no such thing as coincidence in life. All events have a cause. The reference to "witchcraft" is the way in which Africans explain the ultimate cause of things 


\section{African witchcraft in theological perspectives}

(not the immediate cause). Africans believe that evil people (such as sorcerers) cause bad things to happen to good people. In Africa, a scientific explanation of an occurrence will never satisfy. People will never be satisfied with the knowledge that a child suffering from malaria was stung by a mosquito. What they want to know is who had sent the mosquito to bite the child. Someone (an evil-minded person such as a sorcerer) has to be responsible for it. Africans believe that harmful happenings never occur by coincidence. Someone causes something through the use of mystical power. Even the slightest experience of misfortune and sorrow is blamed on the misuse of mystical power. Someone will and must therefore be blamed. In this sense, "witchcraft" provides an answer to the "why question". What it does is it proclaims someone to be responsible for the misfortune. Moreover - when people know that a specific person is responsible, then action can be taken to prevent or to remove the evil.

The terrible consequence of this type of theodicy (or scapegoat thinking) is that someone has to be identified as the culprit responsible for the evil. Whenever there is evil, there has to be witch causing it and this witch will have to be removed from society. Because so many bad things happen in life, people are constantly looking for witches to blame. Somewhere out there must be a guilty one that needs to be removed from society. The witch will always be the other one. In Africa I am never the witch (or the sinner). Evil is what others do to me, not what I do to them. ${ }^{8}$ Somewhere I will find someone to blame. I must make sure that I am not the one that will be blamed. When the witch-hunt is on, I must look for someone to blame. I must look for someone to sacrifice - before they sacrifice me (Mbiti 1975:167-169; Hammond-Tooke 1993:174-178).

\subsection{Positive aspects about this type of theodicy}

To be fair, one has to acknowledge that notwithstanding the negative consequences of this theodicy, there are also has some positive dimensions to it.

Firstly, the fear of others - namely the fear that others would use magic against you in their defence against your evil intentions - deters people from offences such as stealing. Moreover, - in the presence of constant suspicion of witchcraft, people tend to be more cautious and tend to avoid any wrongdoing. It thus has a stabilising effect in relationships among people living close together (Müller \& Ritz-Müller 1999:138-169, 238, 294).

\footnotetext{
${ }^{8}$ We can explain this belief by referring to the faculty of "conscience". In traditional Africa, "conscience" is not the realisation that I have done something wrong, but that someone threatens me. The Xhosa word Andinasazela (I have no conscience) means: I see no evil coming my way (cf Bosch 1974:75-76).
} 
Secondly, talk about witchcraft also has an educational function. It keeps the tribe's norms and values alive. Trough talk about witchcraft children learn about the good values of society, such as harmony, good order, good neighbourliness, good company, cooperation, sharing, honesty, transparency and equitableness. Children are taught that witches are unsociable people. They are people that eat alone; they do not share food. They show no solidarity. They are arrogant people; they do not greet others. They are people who reject all normal things of society. By talking about witchcraft, children are constantly reminded of what social life is all about and what not. Education on witchcraft teaches children that nonconformity is dangerous and that one should not depart from accepted norms, because it raises the suspicion of others and can lead to isolation and eventual destruction (Mbiti 1985:200-201; Russell 1987:416; Sundermeier 1990:230; Magesa 1998:184-188).

Thirdly, the removal of witches from society (by public execution) is important in societies where the absence of a state forces society to create its own judicial system. It is generally accepted that no society can function when evil practices control certain areas of public life. In Africa, where the witch is the personification of evil, such evil must also be removed from society. Witchhunts make life bearable again. It is the cleaning of a town or a kraal. It is the sign of a society that needed a new start (Sundermeier 1990:232; HammondTooke 1993:174).

\subsection{Typical African, or universal?}

Westerners will now easily say: "How awful!" They should rather refrain from such reactions, because they think and act in a similar way. I have already referred to our brutal, bloody European history that bears witness to thousands of witch-killings. We should also briefly concentrate on the fruits of our "Enlightenment". I have referred to various scholars who assert that humanity can only solve the problem of witchcraft through a process of "enlightenment". According to these scholars scientific development, secular education and religious apathy would be able to save humanity from this evil. I do not subscribe to this presumption.

The German philosopher Odo Marquard (1982) and the German theologian Oswald Bayer (1984:9-22; 1991:201-207) have both convincingly argued that the Enlightenment project (as a rejection of the classical theodicy) in itself ends in some kind of a witch-hunt. If man accuses God of an imperfect world, forces him into retirement, takes over the responsibility to create a perfect world - and then fails to produce one - then one must find a scapegoat - someone to blame. Even the modern Western world, the world of the "Enlightenment", knows how to "deal" with culprits. It knows how to 
remove the accused from society. Therefore, not much has changed - only the methods by which scapegoats are dealt with have changed (For more information, please refer to René Girard (1988)).

\section{CONCLUSION}

I commenced by stating that we as theologians can and should make a positive contribution towards solving the problems related to witchcraft. I also stated that our main contribution lies in providing an understanding of this phenomenon within the context of the African worldview. However, if our contribution were to stop at this point, we can expect to be severely criticised by others. People such as Minnaar (1991:56) for instance, accuse the churches in Venda for their total inertia in the wake of the witch-killings that take place in the area. The churches do not even criticise these acts in public or in sermons, because the killings are understood as being part of the Venda reality, and should therefore not be interfered with. Our understanding of reality will have to lead to action of some kind.

I cannot agree with Parrinder (1981:134) and the SANPAD Report (2003:7, 33-35) that emancipation, civilisation, better laws, Western education and more hospitals would on its own overcome the problems related to witchcraft (although these efforts are obviously important). It is not true (as Küng 1994:702 advocates) that the Enlightenment process alone led to the demise of witchcraft in Europe. The development of Christian theology played a decisive role in overcoming this tragedy. I am therefore convinced that the development of theology in Africa will also free this continent from this vicious cycle of fear and murder. When people develop a new understanding of reality and realise that they could handle the complexities of this world in a different, more effective way - then they will also act differently, speak differently and live differently.

I see it as the task of the church to promote knowledge of and an understanding of at least the following themes and sub-themes:

- $\quad$ Protection by the triune God.

- God as creator is not a Deus otiosius. He is also the sustainer of life.

- The cross of Christ is a symbol of power over evil forces.

- The Holy Spirit is "God-with-us".

- Human dignity of every individual.

- Every person is a creature of God and has a right to live.

- Bewitchment of people is dehumanisation. 
- $\quad$ Accepting and fighting sin.

- Acceptance of own sinfulness. Do not blame others.

- Jealousy must not lead to murder (Cain and Abel).

- Focus on the love commandment.

- Belief that evil is self-destructive and is destroyed by God.

- Evil cannot continue to exist. It destroys itself (God allows that). God sees to it that evil is destroyed.

\section{Works consulted}

Bähre, E 2002. Witchcraft and the exchange of sex, blood and money among Africans in Cape Town, South Africa. Journal of Religion in Africa 32, 300334.

Bayer, O 1984. Aus Glauben leben: Über Rechtfertigung und Heiligung. Stuttgart: Calwer Verlag.

Bayer, O 1991. Die offene Frage der Theodizee, in Autorität und Kritik, 201-207. Tübingen: Mohr.

Bosch, D 1974. Een missionair dilemma in Afrika: Het probleem van de kwaad, in Het Evangelie in Afrikaans gewaad, 62-91. Kampen: Kok.

Bosch, D 1987. The problem of evil in Africa: A survey of African views on witchcraft and of the response of the Christian church, in De Villiers, P (ed), Like a roaring lion ... Essays on the Bible, the church and demonic powers, 38-62. Pretoria: UNISA. (C B Powell Bible Centre.)

Bongmba, E 2000. Eros as a theological response to TFU (witchcraft). JTSA 106, 1733.

Brück, A 1959. s v Hexen: Hexenglaube im Christentum. RGG III, 307-310.

Campbell, S 1998. Called to heal: Traditional healing meets modern medicine in southern Africa today. Halfway House: ZEBRA.

Crafford, D 1996. African traditional religions, in Meiring, $\mathrm{P}$ (ed), A world of religions: A South African perspective, 1-26. Pretoria: Kagiso.

Decker, R 2003. Die Päpste und die Hexen: Aus den geheimen Akten der Inquisition. Darmstadt: WBG.

Di Nola, A 1990. Der Teufel: Wesen, Wirkung, Geschichte. München: Diederichs.

Ferdinando, K 1999. The triumph of Christ in African perspective: A study of demonology and redemption in the African context. Carlisle: Paternoster Press.

Fourie, H C M 1921. Amandebele van Fene Mahlangu en hun religieus-sociaal leven. Zwolle: La Rivière \& Voorhoeve. D Theol Proefschrift, Utrecht.

Girard, R 1988. Der Sündenbock. Zürich: Benziger.

Gyekye, K 1998. The problem of evil: An Akan perspective, in Eze, E C, African philosophy: An anthology, 468-471. Oxford: Blackwell.

Haag, H 1978. Vor dem Bösen ratlos? München: Piper.

Hambrock, R 1991. Religion, in Myburgh, A (ed). Anthropology for Southern Africa, 111-139. Pretoria: Van Schaik.

Hammond-Tooke, D 1989. Rituals and medicines. Johannesburg: A D Donker.

Hammond-Tooke, D 1993. The roots of black South Africa. Johannesburg: Jonathan Ball. 
Hanekom, C 1972. Aspekte van die religieuse organisasie van die Mamabolo, in Eloff, J \& Coertze, R, Etnografiese studies in Suidelike Afrika, 96-145. Pretoria: Van Schaik.

Hauschild, W-D 1999. Lehrbuch der Kirchen- und Dogmengeschichte, Band 2. Reformation und Neuzeit. Gütersloh: Gütersloher Verlagshaus.

Haustein, J 2000. s v Hexen. RGG IV, 1719-1722.

Hermanni, F 2002. Das Böse und die Theodizee: Eine philosophisch-theologische Grundlegung. Gütersloh: Kaiser/Gütersloher Verlagshaus.

Holland, H 2001. African magic: Traditional ideas that heal a continent. Sandton: Penguin.

Hund, J 2000. Witchcraft and accusations of witchcraft in South Africa: Ontological denial and suppression of African justice. The Comparative and International Law Journal of Southern Africa 33(3), 366-389.

Hund, J (ed) 2003. Witchcraft violence and the law in South Africa. Pretoria: Protea. Kriel, A 1996. Eenders dink, eenders doen? Kaapstad: Lux Verbi.

Krige, E [1950] 1981. The social systems of the Zulus, 8. Impression. Pietermaritzburg: Shuter \& Shooter.

Küng, H 1994. Das Christentum: Wesen und Geschichte. 2. Aufl. München: Piper.

Leininger, M 1994. Witchcraft practices and psychocultural therapy with urban U S families, in Nursing and anthropology: Two worlds to blend, 299-316. Columbus: Greyden.

Magesa, L [1997] 1998. African Religion: The moral traditions of abundant life. New York: Orbis Books.

Magubane, P 1998. Vanishing cultures of South Africa: Changing customs in a changing world. Cape Town: Struik.

Marquard, O 1982. Der angeklagte und der entlastete Mensch in der Philosophie des 18. Jahrhunderts, in Abschied vom Prinzipiellen, 39-66. Stuttgart: Reclam.

Marwick, M 1987. Witchcraft: African witchcraft, in Eliade, M (ed), The Encyclopedia of Religion, 423-428. London: McMillan.

Mashangoane, P 2001. The Gender implications of witchcraft violence and strategies to combat it. De Jure 34(3), 488-496.

Mbiti, J 1975. Introduction to African religion. Oxford: Heinemann.

Mbiti, J [1969] 1985. African religions and philosophy. 11th ed. London: Heinemann.

Myburgh, A (ed) 1991. Anthropology for Southern Africa. Pretoria: Van Schaik.

Mihálik, J \& Cassim, Y 1993. Ritual murder and witchcraft: A political weapon? South African Law Journal 110(1), 127-140.

Minnaar, A e a 1991. The witches of Venda: Politics in magic potions. Indicator 9(1), 53-58.

Mohr, H 1993. Hexe/Hexenmuster, in Cancikea et al (Hrsg), Handbuch religionswissenschaftlicher Grundbegriffe, Band III, 122-138. Stuttgart: Kohlhammer.

Mönnig, H 1967. The Pedi. Pretoria: Van Schaik.

Müller, K \& Ritz-Müller, U 2000. Soul of Africa: Magical rites and traditions. Cologne: Könemann.

Niehaus, I 1997. "A witch has no horn": The subjective reality of witchcraft in the South African Lowveld. African Studies 56(2), 251-278.

Niehaus, I 2001. Witchcraft, power and politics: Exploring the occult in the South African Lowveld. Claremont: David Philip. 
Niehaus, I 2002. Perversion of power: Witchcraft and the sexuality of evil in the South African Lowveld. Journal of Religion in Africa 32, 269-299.

Nyirongo, L 1997. The gods of Africa or the God of the Bible?: The snares of African traditional religion in Biblical perspective. Potchefstroom: IRS. (Series F2. No 7.)

Olupona, J (ed) 1991. African traditional religions in contemporary society. Minnesota, MN: Paragon House.

Parrinder, E G [1954] 1981. African traditional religion, 3rd ed. London: Sheldon Press.

Peltzer, K 2001a. Management of witchcraft (bolôyi) in an urban and a rural community in the Northern Province of South Africa. Acta Criminologica 14(1), 104-110.

Peltzer, K 2001b. Attitudes and beliefs of police officers towards witchcraft (bolôyi) and their intervention role in the Northern Province, South Africa. Acta Criminologica 14(2), 100-107.

Ray, B 1976. African religions: Symbol, ritual, and community. Englewood, NJ: Prentice-Hall.

Rehberger, C 1992. Die Verteufelung der Frau als Hexe in den Hexenverfolgungen des späten Mittelalters und der frühen Neuzeit. EvTh 52, 65-75.

Reyneke, J 1972. Towery by die Bakgatla-baKgafêla, in Eloff, J \& Coertze, R, Etnografiese studies in Suidelike Afrika, 146-181. Pretoria: Van Schaik

Rosen, L 1972. An ideal typology of witchcraft beliefs and accusations. African Studies 31(1), 25-30.

Russell, J 1987. $s$ v Witchcraft: Concepts of witchcraft, in Eliade, M (ed), The encyclopedia of religion, 415-423. London: McMillan.

SANPAD 2003. Crossing witchcraft barriers in South Africa: Exploring witchcraft accusations: Causes and solutions. Utrecht: Faculty of Social Sciences. University of Utrecht. (SANPAD Research Report.)

Schormann, G 1986. s v Hexen. TRE, 297-304.

Sogolo, G 1998. The concept of cause in African thought, in Coetzee, P H \& Roux, A $\mathrm{P}$ J (eds) 1998. Philosophy from Africa: A text with readings, 177-185. Halfway House: International Thomson Publishing.

Stadler, J 1996. Witches and witch-hunters: Witchcraft, generational relations and life cycle in a Lowveld village. African Studies 55(1), 87-110.

Stiglmayr, E 1959. s v Hexen: Religionsgeschichtlich. RGG III, 307-308.

Sundermeier, T [1988] 1990. Nur gemeinsam können wir leben: Das Menschenbild schwarzafrikanischer Religionen. 2. Aufl. Gütersloh: Mohn. (GTB 784.)

Sundermeier, T 1999. Was ist Religion?: Religionswissenschaft im theologischen Kontext: Ein Studienbuch. Gütersloh: Kaiser/Gütersloher Verlagshaus. (Theol Bücherei 96. Studienbücher.)

Sundkler, B \& Steed, C 2000. A history of the church in Africa. Cambridge:

Cambridge University Press. (Studia Missionalia Uppsaliensia LXXIV.)

Sunter, C 1993. Pretoria will provide and other myths. Cape Town: Tafelberg.

Thorpe, S A 1991. African traditional religions: An introduction. Pretoria: UNISA.

Thorpe, S A 1993. Shamans, medicine men and traditional healers. Pretoria: UNISA.

Turaki, Y 1999. Christianity and African gods: A method in theology. Potchefstroom: IRS (Series F2. No 75.) 
African witchcraft in theological perspectives

Van Beek, W E A 1994. The innocent sorcerer: Coping with evil in two African societies (Kapsiki \& Dogon), in Blakely, T, Van Beek, W, Thomson, D (eds), Religion in Africa: Experience \& expression, 197-228. Portsmouth: Heinemann.

Van Niekerk, A 1992. Sáám in Afrika. Kaapstad: Tafelberg.

Vierzig, S 1984. Das Böse. Stuttgart: Kohlhammer. (Taschenbücher. Religion. Band 1040.) 